\title{
ISOLASI DAN KARAKTERISASI GELATIN DARI TULANG AYAM DENGAN METODE ASAM
}

\author{
Akyunul Jannah, Anik Maunatin, Arin Windayanti, Yuana Findianti dan Zulfiatul Mufidah
}

Jurusan Kimia, Fakultas Sains dan Teknologi UIN Maulana Malik Ibrahim Malang

\begin{abstract}
The purpose of this study was to determine the quality of gelatin by using raw materials bone chicken (Gallus gallus domesticus) and the Broiler chickens for differences in the concentration of acetic acid immersion process ( curing ). The method used in this study is the preparation and broiler chicken bones, isolation of gelatin with various concentration of acetic acid in the curing process, the process of hydrolysis, extraction temperature rise and gelatin with gelatin obtained include the characterization of protein, water, ash and metal.

The results showed the highest yield of gelatin produced from Broiler chicken bone types with acetic acid concentration of $1 \%$, ie $3.25 \%$. Gelatin highest protein content of $86.27 \%$ of the types of Broiler chicken bone with acetic acid concentration of $1.5 \%$. Lowest ash content of $15.7 \%$ gelatin from bone types Broiler chicken with $1 \%$ acetic acid concentration, and from analysis using AAS contained $\mathrm{Cu}$ at $0.6 \%$ (of the type of chicken bones, acetic acid concentration of $0.5 \%$ ) and $\mathrm{Cu}$ metal content of $1.1 \%$ (of the type of Broiler chicken bones, acetic acid concentration of $1 \%$. highest moisture content of $0.17 \%$ gelatin from bone types Kampung chicken with $1 \%$ acetic acid concentration .
\end{abstract}

Key words: gelatin, protein, ash, water content and $\mathrm{Cu}$

\section{PENDAHULUAN}

Negara Indonesia ini adalah negara yang mayoritas warganya beragama muslim. Hal ini berkaitan dengan hukum syariat Islam yang mewajibkan umatnya untuk mengkonsumsi sesuatu barang yang jelas kehalalannya. Bukan dari bahannya saja yang kita lihat, tetapi juga cara untuk memperolehnya pun harus kita perhatikan dengan jelas. Hal ini sesuai dengan firman Allah SWT dalam surat Al-Maidah ayat 3 yang menerangkan bahwa diharamkan mengkonsumsi bangkai, darah, daging babi atau daging yang disembelih atas nama selain Allah SWT, maka janganlah kita sesekali mengkonsumsinya karena hal tersebut termasuk perbuatan orang-orang kafir. Apabila terpaksa mengkonsumsinya karena kelaparan atau tanpa sengaja berbuat dosa, maka sesungguhnya Allah Maha Pengampun lagi Maha Penyayang.

Pemanfaatan gelatin dalam industri pangan dan non pangan semakin luas, namun bahan baku yang digunakan sebagai sumber gelatin masih banyak berasal dari babi. Indonesia mengimpor gelatin dari negara-negara seperti: Perancis, Jepang, India, Brazil, Jerman, Cina, Argentina, dan
Australia. Impor gelatin tahun 2000 mencapai 2700 ton telah meningkat menjadi 6233 ton senilai US \$ 6.962.237 (Peranginangin, 2007). Tahun 1999 (sampai dengan bulan Juni) sebanyak $2.371 .738 \mathrm{~kg}$ dengan nilai US\$ 9.095.440, sedangkan pada tahun 2001 impor gelatin tersebut meningkat mencapai $4.291 .579 \mathrm{~kg}$ dengan nilai US\$ 10.749.199 (BPS, 2004).

Gelita Group (2008) melaporkan bahwa bahan baku yang digunakan oleh para produsen gelatin dunia mayoritas adalah kulit babi (46\%), disusul oleh kulit sapi (28\%), tulang sapi (24\%), dan bahan lainnya $(2 \%)$. Status haram pada produkproduk berbahan dasar babi dan kasus zoonosis sapi gila di negara-negara produsen gelatin (Eropa dan Amerika) sama sekali tidak menurunkan permintaan pasar Indonesia terhadap gelatin impor. Hal ini terbukti dengan terus meningkatnya nilai impor gelatin Indonesia.

Tingginya kebutuhan akan gelatin yang halal dan sehat di Indonesia dapat dipenuhi bila tulang ayam dapat dimanfaatkan sebagai bahan baku. Menurut Septimus (1961), tulang ayam tersusun oleh komponen utama kalsium fosfat $(57,35 \%)$, 
kolagen $(33,3 \%)$, dan kalsium karbonat $(3,85 \%)$. Persentase kolagen ini memang tidak sebanyak kulit sapi yang menurut Jones (1977) mencapai 89\%.

Terdapat beberapa jenis ayam yang ada di Indonesia, salah satu ayam yang dibudidayakan adalah Ayam Pedaging (Broiler) dan ayam kampung. Ayam Broiler adalah ayam ras yang mampu tumbuh cepat sehingga dapat menghasilkan daging dalam waktu relatif singkat (5-7 minggu). Pertumbuhan ayam broiler yang begitu cepat akan menghasilkan limbah yang sangat melimpah. Limbah dari ayam broiler ini berupa tulang ayam yang tidak dimanfaatkan lagi. Data statistik pertanian tahun 2003 yang dilaporkan oleh Suryana (2004) menunjukkan bahwa produksi daging ayam sebanyak 973.000 ton $(973.000 .000 \mathrm{~kg})$. Bila berat ayam yang dipotong berkisar $1,5 \mathrm{~kg}$ maka jumlah ayam yang dipotong selama tahun 2003 adalah 648.666.667 (973.000.000:1,5) ekor dan jumlah potongan ceker atau kaki ayam yang dihasilkan 1.297.333.333 potong.

Sedangkan ayam kampung merupakan salah satu unggas yang dikonsumsi manusia untuk memenuhi kebutuhan proteinnya. Produksi daging ayam memenuhi $62 \%$ dari kebutuhan daging Nasional dan sebanyak $16 \%$ dari kebutuhan tersebut terpenuhi dari ayam buras. Populasi ayam buras di Indonesia mencapai 272.251.141 ekor (2007), pada tahun 2008 sebanyak 243.423.389 ekor, dan pada tahun 2009 sebanyak 261.420.401 ekor (Direktorat Peternakan Nasional).

Metode pembuatan gelatin yang digunakan adalah metode asam dan menghasilkan gelatin tipe A. Metode asam lebih efektif dan efisien dalam produksi gelatin di industri dibandingkan metode basa yang menghasilkan gelatin tipe $B$. Kualitas gelatin tipe A lebih tinggi dibandingkan gelatin tipe $\mathrm{B}$, sehingga mayoritas permintaan gelatin di dunia adalah gelatin tipe A. Salah satu sifat kimia gelatin yang menentukan mutu gelatin adalah kadar protein dan kandungan logam. Menurut Deman (1997) kandungan merkuri yang tidak terdeteksi dalam gelatin kulit ikan kakap merah menunjukkan bahwa gelatin tersebut masih memenuhi syarat yang ditetapkan yaitu maksimum 0,5 $\mathrm{mg} / \mathrm{kg}$. Hasil yang didapat dari analisis pengujian logam berat timbal $(\mathrm{Pb})$ dan merkuri $(\mathrm{Hg})$ menunjukkan bahwa gelatin yang diproduksi dari kulit ikan kakap merah dapat digunakan dalam produk konsumsi yaitu produk pangan dan produk farmasi.

Pada penelitian ini akan dilakukan isolasi gelatin dari tulang ayam kampung dan tulang broiler menggunakan variasi konsentrasi pelarut asam asetat dalam proses perendaman (curing) dan karakterisasi kualitas gelatin yang dihasilkan.

\section{METODE PENELITIAN Preparasi Tulang Ayam Kampung dan Broiler}

Bahan dasar penelitian ini adalah tulang ayam kampung dan broiler hasil limbah. Tulang yang diperoleh terlebih dahulu dibersihkan dari sisa-sisa daging yang masih menempel, dipotong hingga berukuran kecil-kecil, dicuci, ditiriskan dan diangin-anginkan hingga tidak ada lagi air yang menetes, lalu ditimbang beratnya.

\section{Isolasi Gelatin}

Isolasi gelatin dilakukan melalui dua tahap yaitu hidrolisis kolagen dengan proses curing (perendaman) asam dan dilanjutkan dengan proses ekstraksi.

\section{Tahap Hidrolisis}

Pada tahap ini dilakukan proses curing asam dengan larutan asam asetat $\left(\mathrm{CH}_{3} \mathrm{COOH}\right)$. Untuk mendapatkan konsentrasi optimum dalam proses curing asam, maka dilakukan proses curing dengan variasi konsentrasi larutan $\mathrm{CH}_{3} \mathrm{COOH}$ dengan waktu curing selama 3 hari. Masing-masing sebanyak \pm 50 gr tulang kaki ayam kampung dimasukkan dalam 4 botol sampel $1 \mathrm{~L}$ yang berbeda, kemudian ditambahkan larutan $\mathrm{CH}_{3} \mathrm{COOH} 0,5 ; 1,0$; 1,5 dan $2,0 \%(\mathrm{v} / \mathrm{v})$ dengan rasio berat 
tulang terhadap larutan yang digunakan (1:8) dengan pengadukan dan ditutup. Proses curing kemudian dicuci dengan aquades sampai filtrat hasil pencucian menunjukkan $\mathrm{pH}$ netral dan ditiriskan.

\section{Tahap Ekstraksi Pengentalan dan Pengeringan Gelatin}

Tulang ayam hasil curing asam maupun basa kemudian diekstraksi dengan waterbath pada suhu $70^{\circ} \mathrm{C}$ selama 20 menit. Ekstrak yang diperoleh kemudian disaring, diukur volumenya, ditempatkan dalam wadah sampel dan didinginkan dalam wadah sampel dan didinginkan dalam lemari pendingin sampai mengental dan berbentuk gel. Setelah mengental, gel yang diperoleh dikeringkan dalam oven pada suhu $70^{\circ} \mathrm{C}$ selama 24 jam, didinginkan dalam desikator dan beratnya ditimbang.

\section{Karakterisasi Gelatin}

\section{a. Penentuan Kadar Air Secara Thermogravimetri}

Sebanyak 0,5 gr sampel gelatin dimasukkan dalam cawan porselin, kemudian dimasukkan dalam oven dan dikeringkan pada suhu $105{ }^{\circ} \mathrm{C}$ selama 24 jam. Lalu didinginkan dalam desikator dan ditimbang hingga diperoleh berat konstan. Dihitung kadar air menggunakan rumus:

$$
\text { kadar air }=\frac{(b-c)}{b-a} \times 100 \%
$$

$$
\begin{aligned}
\text { Di mana } & \\
\mathrm{a}= & \text { bobot cawan kososng } \\
\mathrm{b}= & \text { bobot sampel }+ \text { cawan sebelum } \\
& \text { dikeringkan } \\
\mathrm{c}= & \begin{array}{l}
\text { bobot cawan }+ \text { sampel setelah } \\
\text { dikeringkan }
\end{array}
\end{aligned}
$$

\section{b. Penentuan Kadar Abu}

Penentuan kadar abu merupakan kelanjutan dari analisis kadar air. Cawan yang berisi sampel kering dimasukkan dalam tanur pada suhu $600{ }^{\circ} \mathrm{C}$ selama 6 jam, kemudian didinginkan dalam desikator dan ditimbang hingga didapat berat kostan (d). Kadar abu dihitung menggunakan rumus:

$$
\text { kadar } a b u=\frac{(d-a)}{b-a} \times 100 \%
$$

Di mana :

$\mathrm{a}=$ bobot cawan kososng

$\mathrm{b}=$ bobot sampel + cawan sebelum dikeringkan

$\mathrm{d}=$ bobot cawan + sampel setelah dikeringkan

\section{c. Analisis Logam Cu}

Kandungan logam berat yang ingin dianalisa adalah Arsen, Tembaga dan seng dengan menggunakan Absorbsi Atom Spektrofotometer (AAS). Sampel $\mathrm{HCl}$ sebanyak 5-6 mL ditambahkan ke dalam cawan berisi abu hasil pengabuan kering, kemudian dipanaskan di atas hot plate dengan pemanasan rendah sampai kering. Setelah itu ditambahkan $15 \mathrm{ml} \mathrm{HCl} 3 \mathrm{~N}$, lalu cawan dipanaskan di atas pemanas sampai mulai mendidih. Setelah didinginkan dan disaring, filtrat dimasukkan ke dalam labu takar dan diencerkan dengan air sampai tanda tera. Blanko disiapkan menggunakan pereaksi yang sama. Alat AAS diset sesuai interuksi dalam manual alat tersebut. Larutan standar logam, blanko dan sampel diukur. Selama penetapan sampel, dilakukan pemeriksaan apakah nilai standar tetap konstan. Kemudian dibuat kurva standar untuk masing-masing logam (nilai absorbsi/emisi vs konsentrasi logam dalam $\mu \mathrm{g} / \mathrm{ml}$ ).

\section{d. Analisis Kadar Protein dengan Metode Kjeldahl}

Sampel

dimasukkan dalam labu Kjeldahl $100 \mathrm{~mL}$, kemudian ditambahkan dengan katalis $(1,2$ gr $\mathrm{Na}_{2} \mathrm{SO}_{4}$ dan 1 gr $\mathrm{CuSO}_{4}$ dan $2 \mathrm{~mL}$ $\mathrm{H}_{2} \mathrm{SO}_{4}$ pekat). Dilakukan destruksi sampai larutan menjadi jernih. Setelah itu didinginkan kemudian sampel didestilasi dan ditambahkan $35 \mathrm{~mL}$ aquades dan 10 $\mathrm{mL} \mathrm{NaOH} \mathrm{50 \% .} \mathrm{Hasil} \mathrm{destilasi} \mathrm{dalam}$ erlenmeyer $125 \mathrm{~mL}$ yang berisi $5 \mathrm{~mL}$ $\mathrm{H}_{3} \mathrm{BO}_{3}$ kemudian dititrasi dengan $\mathrm{HCl} 0,02$ $\mathrm{N}$ dengan menggunakan indikator. Hal yang sama dilakukan untuk blanko. 


\section{HASIL DAN PEMBAHASAN Rendemen}

Rendemen dihitung berdasarkan persentase berat gelatin yang dihasilkan terhadap berat awal tulang yang digunakan. Rendemen yang diperoleh dipengaruhi oleh jumlah kolagen yang terkonversi menjadi gelatin.

Tabel 1. Rendemen Gelatin Tulang Ayam Kampung dan Ayam Broiler

\begin{tabular}{|l|c|}
\hline \multicolumn{1}{|c|}{ Sampel (asam asetat) } & $\begin{array}{c}\text { Rendemen } \\
(\%)\end{array}$ \\
\hline Tulang Ayam Kampung 0,5\% & 1,24 \\
\hline Tulang Ayam Kampung 1\% & 1,04 \\
\hline Tulang Ayam Broiler 1\% & 3,25 \\
\hline Tulang Ayam Broiler 1,5\% & 1,99 \\
\hline Tulang Ayam Broiler 2\% & 1,93 \\
\hline
\end{tabular}

Tabel 1 menunjukkan bahwa semakin besar konsentrasi asam asetat yang digunakan, maka semakin kecil rendemen gelatin yang dihasilkan. Semakin tinggi konsentrasi asam yang digunakan, maka akan semakin banyak pula kolagen yang terhidrolisis dan terdegradasi. Hal ini akan menyebabkan ikatan-ikatan peptida asam amino yang merupakan struktur utama dari kolagen mengalami degradasi. Adanya peristiwa degradasi dari komponen penyusun kolagen ini menyebabkan jumlah kolagen menjadi larut dan ikut terbuang pada proses pencucian ossein berlangsung, akibatnya rendemen yang diperoleh semakin menurun.

\section{Karakteristik Gelatin}

\section{a. Kadar Air}

Pengujian kadar air dalam penelitian ini bertujuan untuk mengetahui kandungan air dalam gelatin. Kadar air gelatin sangat berpengaruh terhadap umur simpan, karena erat kaitannya dengan aktivitas mikroorganisme yang terjadi selama gelatin tersebut disimpan serta dapat mempengaruhi penampakan, tekstur serta cita rasa bahan makanan hasil olahan menngunakan gelatin tersebut.

Tabel 2. Nilai Kadar Air Gelatin Tulang Ayam Kampung dan Tulang Ayam Broiler

\begin{tabular}{|l|c|}
\hline \multicolumn{1}{|c|}{ Sampel (asam asetat) } & Kadar Air (\%) \\
\hline Tulang Ayam Kampung 0,5\% & 0,076 \\
\hline Tulang Ayam Kampung 1\% & 0,163 \\
\hline Tulang Ayam Broiler 1\% & 0,102 \\
\hline Tulang Ayam Broiler 1,5\% & 0,123 \\
\hline Tulang Ayam Broiler 2\% & 0,13 \\
\hline
\end{tabular}

Tabel 2 menunjukkan bahwa semakin besar konsentrasi asam asetat yang digunakan, maka semakin besar kadar air yang dihasilkan, hal ini disebabkan karena konsentrasi asam yang tinggi memiliki kemampuan yang lebih besar dan kuat dalam menghidrolisis kolagen, menyebabkan terjadinya pemendekan rantai-rantai peptide pada kolagen, sehingga menjadikan kesempatan untuk menyerap air semakin banyak.

Kadar air gelatin yang diperoleh pada penelitian ini masih dalam batas Standar Nasional Indonesia 1995, karena menurut standar SNI kadar air maksimum gelatin yang diperbolehkan adalah $6 \%$.

\section{b. Kadar Abu}

Pengukuran kadar abu bertujuan untuk mengetahui besarnya kandungan mineral yang terdapat dalam gelatin dan merupakan salah satu parameter penting untuk menilai kualitas gelatin terutama dalam hal kemurnian gelatin. Menurut Sudarmadji et. al. (1989), abu adalah zat anorganik sisa hasil pembakaran suatu bahan organik.

Tabel 3. Nilai Kadar Abu Gelatin Tulang Ayam Kampung dan Tulang Ayam Broiler

\begin{tabular}{|l|c|}
\hline \multicolumn{1}{|c|}{ Sampel (asam asetat) } & Kadar abu (\%) \\
\hline Tulang Ayam Kampung 0,5\% & 15,8 \\
\hline Tulang Ayam Kampung 1\% & 27,5 \\
\hline Tulang Ayam Broiler 1\% & 15,7 \\
\hline Tulang Ayam Broiler 1,5\% & 25,1 \\
\hline Tulang Ayam Broiler 2\% & 33,1 \\
\hline
\end{tabular}

Tabel 3 menunjukkan bahwa semakin besar konsentrasi asam asetat yang digunakan, maka semakin besar kadar abu yang dihasilkan baik pada tulang ayam kampong maupun broiler. Kadar abu gelatin hasil penelitian ini masih cukup tinggi jika dibandingkan dengan Standar 
Nasional Indonesia 1995 (maksimum $3,25 \%)$.

Berdasarkan analisis kadar abu diperoleh hasil yang cukup besar (diatas nilai standart SNI) ini menandakan kandungan mineral-mineral terutama logam juga cukup tinggi. Berdasarkan hasil analisis AAS diperoleh bahwa logam $\mathrm{Cu}$ sebesar $0,6 \%$ (dari jenis tulang ayam kampung, konsentrasi asam asetat $0,5 \%$ ) dan kadar logam $\mathrm{Cu}$ sebesar 1,1\% (dari jenis tulang ayam Broiler, konsentrasi asam asetat $1 \%$. Berdasarkan standart SNI logam $\mathrm{Cu}$ yang ada di gelatin maksimal $30 \mathrm{mg} / \mathrm{kg}$ atau sebesar $0,3 \%$, sehingga dari penelitian ini masih cukup besar nilai kadar logamnya khusunya $\mathrm{Cu}$. Besarnya kadar abu atau logam $\mathrm{Cu}$ khususnya dikarenakan pada ayam kampung maupun Broiler mempunyai tulang yang sangat rapuh yang mudah sekali hancur pada saat perlakuan curing yaitu dalam bentuk Ossein. Ossein dalam bentuk serbuk mudah sekali lolos dalam penyaringan dengan kertas saring biasa sehingga pada saat ekstraksi gelatin serbuk Ossein akan bergabung dengan gelatin.

\section{c. Kadar Protein}

Gelatin dapat diperoleh dari hasil hirolisis kolagen sehingga komponen utama dari gelatin adalah protein. Protein merupakan polimer dari sekitar 21 asam amino yang berlainan dan dihubungkan dengan ikatan peptida (Deman, 1989).

Tabel 4. Hasil kadar protein gelatin tulang ayam kampung dan ayam broiler

\begin{tabular}{|l|c|}
\hline \multicolumn{1}{|c|}{ Sampel (asam asetat) } & $\begin{array}{c}\text { Kadar Protein } \\
(\%)\end{array}$ \\
\hline Tulang Ayam Kampung 0,5\% & 79,66 \\
\hline Tulang Ayam Kampung 1\% & 85,00 \\
\hline Tulang Ayam Broiler 1\% & 78,58 \\
\hline Tulang Ayam Broiler 1,5\% & 81,22 \\
\hline Tulang Ayam Broiler 2\% & 86,27 \\
\hline
\end{tabular}

Pada Tabel 4 menunjukkan bahwa semakin besar konsentrasi pelarut yang diberikan maka akan menghasilkan protein yang besar pula. Hal ini dikarenakan dengan semakin banyak konsentrasi pelarut yang diberikan maka interaksi tulang dengan pelarut semakin kuat. Interaksi inilah yang menyebabkan kalsium dalam tulang dapat terlepas dari tulang ayam. Selain itu juga menyebabkan reaksi pemutusan ikatan hidrogen dan pembukaan struktur koil kolagen, sehingga lebih banyak kolagen (protein) yang terkonversi menjadi gelatin. Kadar protein dalam gelatin juga dapat dipengaruhi oleh baik tidaknya kualitas ossein yang dihasilkan pada proses demineralisasi. Bahan baku juga mempengaruhi kualitas ossein yang dihasilkan. Ward dan Court (1977) menyatakan bahwa kadar protein gelatin bervariasi tergantung spesies hewan penghasil, sumber kolagen dan jenis kolagen.

\section{KESIMPULAN}

Berdasarkan penelitian yang telah kami lakukan, bahwa kualitas Gelatin yang diperoleh dengan variasi jenis tulang ayam dan konsentrasi asam asetat adalah sebagai berikut :

1. Rendemen gelatin tertinggi dihasilkan dari jenis tulang ayam Broiler dengan konsentrasi asam asetat $1 \%$, yaitu sebesar 3,25\%.

2. Kadar air gelatin tertinggi sebesar 0,17 $\%$ dari jenis tulang ayam Kampung dengan konsentrasi asam asetat $1 \%$.

3. Kadar abu gelatin tertinggi sebesar 33,17 $\%$ dari jenis tulang ayam Broiler dengan konsentrasi asam asetat $2 \%$, dan dari hasil pengamatan/analisis menggunakan AAS terdapat logam $\mathrm{Cu}$ sebesar $0,6 \%$ (dari jenis tulang ayam kampung, konsentrasi asam asetat 0,5\%) dan kadar logam $\mathrm{Cu}$ sebesar $1,1 \%$ (dari jenis tulang ayam Broiler, konsentrasi asam asetat $1 \%$.

4. Kadar protein gelatin tertinggi sebesar $86,27 \%$ dari jenis tulang ayam Broiler dengan konsentrasi asam asetat $1,5 \%$.

\section{DAFTAR PUSTAKA}

[SNI] Standar Nasional Indonesia. 06=3735. 1995. Mutu dan Cara Uji Gelatin. Jakarta: Badan Standarisasi Nasional 
Biro Pusat Statistik. 2004. Jumlah Impor dan Ekspor Gelatin di Indonesia. Jakarta: Biro Pusat Statistik

Deman. 1989. Kimia Makanan. Bandung : ITB Press

Gelita Corporation. 2008. Gelatine worldwide. http://www.gelita.com, diakses pada tanggal 30 Juni 2012

Jones. 1977. Uses of Gelatin in Edible Product. Dalam: Ward, A. G dan A. Courd [Ed]. 1997. The Science and Tecnology of Gelatin. New York: Academic Press
Septimus, S. 1961. Anatomy of The Domestic Animal. Mc Graww Hill, New York

Sudarmadji. 1989. Analisa untuk Bahan Makanan dan Pertanian. Yogyakarta: Liberty

Suryana, A.2004 .Ketahanan Pangan Cukup Baik Meski Belum Sempurna, Sinar Tani, Edisi 31 Desember 20036 Januari 2004, No. 3028, Th XXXIV

Ward, A. G. dan A. Courts. 1977. The Science and Technology of Gelatin. Academic Press, New York 